\title{
A Parasitoid Muscidifurax raptor Girault \& Sanders (Insecta: Hymenoptera: Pteromalidae) ${ }^{1}$
}

\author{
Nicholas S. G. Tucker and Phillip E. Kaufman²
}

\section{Introduction}

Muscidifurax raptor Girault \& Sanders, 1910, is a member of the family Pteromalidae. This family includes approximately 3,600 wasp species of which most are insect, arachnid, or plant parasitoids. Several species within this family are important biological control agents of insect pests. Due to human activity, such as inefficient waste management, filth flies and other flies that are considered nuisance species can reach large population sizes if left unchecked. The filth flies can vector many human and livestock pathogens and contribute greatly to the spread of infectious disease. Fly parasitoids act as effective biological control agents of many of these species by killing the fly before it can emerge as an adult.

Pteromalids can be found worldwide under a wide range of environmental conditions. Fly parasitoid wasps associated with livestock production commonly found in North America belong to the genera Muscidifurax, Nasonia, Urolepis, Pachycrepoideus, and Spalangia. The genus Muscidifurax is represented by three species: Muscidifurax raptor, Muscidifurax raptorellus Kogan \& Legner, and Muscidifurax zaraptor Kogan \& Legner. Each species differs to a degree in habitat choice, host choice, and behavior. Some of these wasp species live gregariously as larvae within a host puparium, while most species are solitary as immatures. Similarly, some species prefer constantly wet habitats such as manure, whereas others prefer drier areas, such as manure-soiled straw bedding. The abundance and habitat preference of each parasitoid species can differ between region and season. Adult members of this family are typically between 1-3 mm in length (Rueda and Axtell 1985). Due to their disinterest in non-fly species, these wasps are harmless to humans.

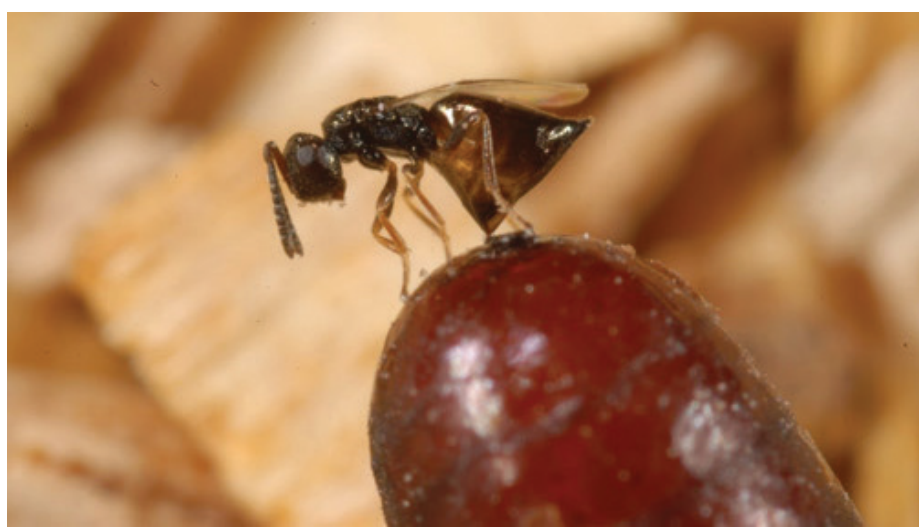

Figure 1. Muscidifurax raptorellus Girault \& Sanders laying an egg in a fly puparium.

Credits: Lyle J. Buss, UF/IFAS

\section{Synonymy}

Muscidifurax raptor Girault \& Sanders, 1910

1. This document is EENY657, one of a series of the Department of Entomology and Nematology, UF/IFAS Extension. Original publication date May 2016. Visit the EDIS website at http://edis.ifas.ufl.edu. This document is also available on the Featured Creatures website at http://entnemdept.ifas.ufl.edu/ creatures/.

2. Nicholas S. G. Tucker; and Phillip E. Kaufman, associate professor; Department of Entomology and Nematology, UF/IFAS Extension, Gainesville, FL 32611 


\section{Distribution}

Muscidifurax raptor can be found in North, Central, and South America, the Caribbean, Africa, the Middle East, Europe, Australia, and many Pacific islands. Typical hosts of this species are commonly found near human establishments and confined livestock. Muscidifurax raptor is one of the most common naturally-occurring house fly pupal parasites on sheep, and dairy and beef cattle farms, as well as on caged-layer poultry operations (Rueda and Axtell 1985). Compared to other fly parasitoids, Muscidifurax raptor is found most commonly in livestock feed and straw, both at indoor and outdoor sites (Smith and Rutz 1991).

\section{Life Cycle and Description}

An adult Muscidifurax raptor is a minute, inconspicuous, black wasp that is classified as a parasitoid, meaning its larval stage feeds on and kills its host. The adult is the only stage during its life cycle wheres its presence is obvious to humans, as its development as an egg, larva, and pupa occur inside the fly puparium (the shell that contains the developing fly pupa), much like a moth develops within a cocoon. Muscidifurax raptor undergoes complete metamorphosis, meaning that it hatches from an egg as a larva, goes through several developmental instars, pupates, and emerges as an adult. The life cycle from egg to adult is completed in $17-22$ days at $26^{\circ} \mathrm{C}$ and $13-15$ days at $27.8^{\circ} \mathrm{C}$ (Rueda and Axtell 1985). The average life span of an adult Muscidifurax raptor is 26 days and is temperature dependent; as temperature increases $\left(15.5^{\circ} \mathrm{C}\right.$ to $\left.32^{\circ} \mathrm{C}\right)$ adult longevity decreases (Lysyk 1999). In the 1999 laboratory study by Lysyk, the temperature at which the maximum number of offspring was produced was $25^{\circ} \mathrm{C}$.

\section{Egg}

The egg is opaque, oblong, and about $0.4 \mathrm{~mm}$ in length. Eggs are placed inside the fly puparium by the female wasp.

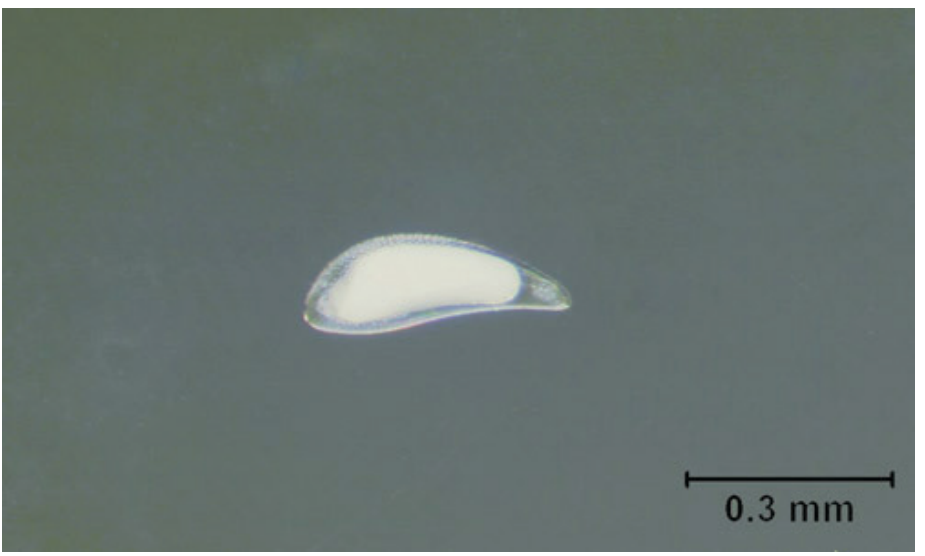

Figure 2. Muscidifurax raptor Girault \& Sanders egg.

Credits: Nicholas Tucker, UF/IFAS

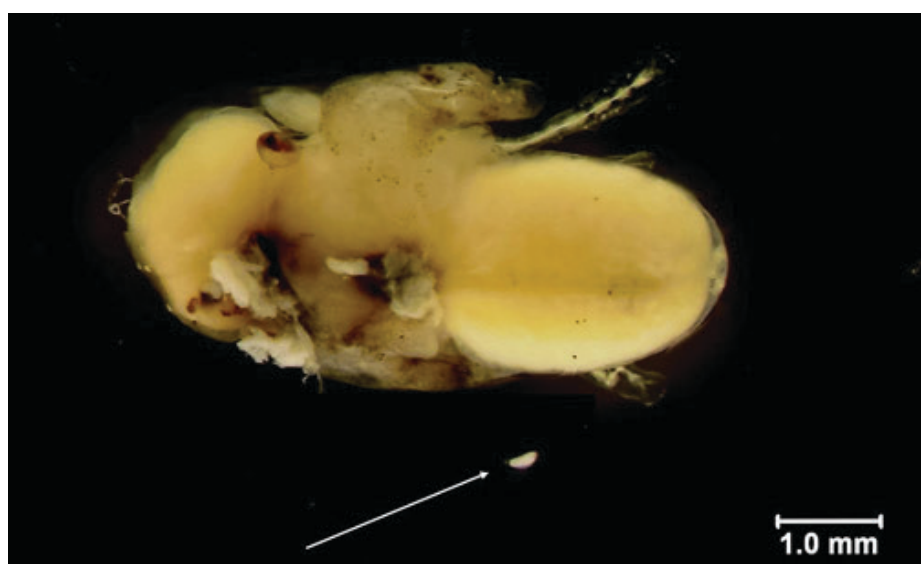

Figure 3. Muscidifurax raptor Girault \& Sanders egg adjacent to Musca domestica L. pupa.

Credits: Nicholas Tucker, UF/IFAS

\section{Larvae}

Muscidifurax raptor larvae are grub-like with visible body segments, opaque to creamy white, and range from $0.5-2.5$ $\mathrm{mm}$ in size. Larvae attach to the fly pupa with their mouthparts in order to feed and are able to move throughout the puparium.

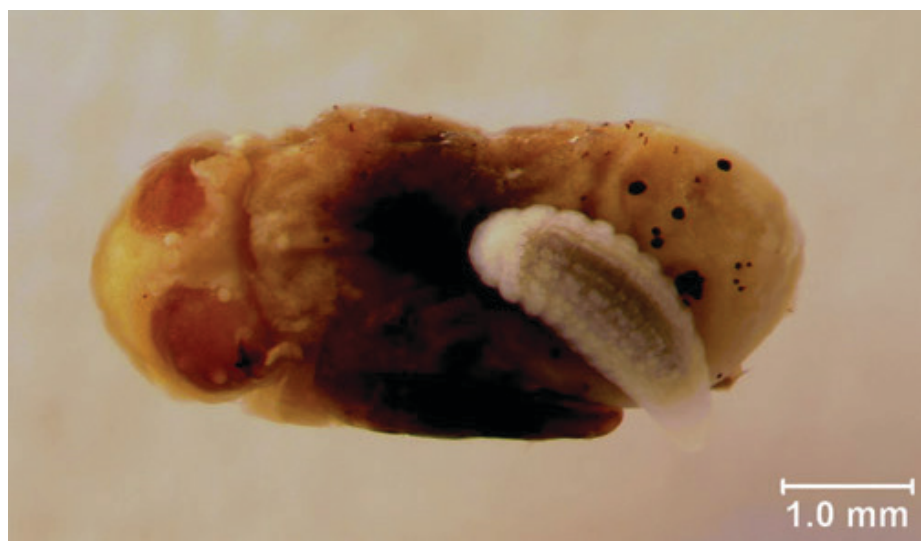

Figure 4. Muscidifurax raptor Girault \& Sanders larva on a Musca domestica L. pupa.

Credits: Nicholas Tucker, UF/IFAS

\section{Pupae}

Muscidifurax raptor pupae strongly resemble the adult stage, but legs and antennae are folded and held close to the body. Muscidifurax raptor does not develop its own puparium as it is protected by the host fly puparium in which it developed. Color changes from creamy white to black as the pupa progresses in development.

\section{Adults}

Adult Muscidifurax raptor range from 1.7-2.5 $\mathrm{mm}$ in length. They are solid black except for their wings, which are colorless. When disturbed, adults will quickly fly short distances. Adults will also fly in order to find a suitable host. 
Female Muscidifurax raptor are immediately receptive to mating and oviposition upon emergence from the host puparia (Morgan 1981). Female Muscidifurax raptor progress through four distinct phases while finding and selecting pupae: finding the host area, locating a host pupa, drumming and drilling, and feeding (Ridgeway and Vinson 1977). This sequence can take 10-15 minutes (Morgan 1981). Adults can penetrate up to $5 \mathrm{~cm}$ of manure in search of fly pupae (Rueda and Axtell 1985).

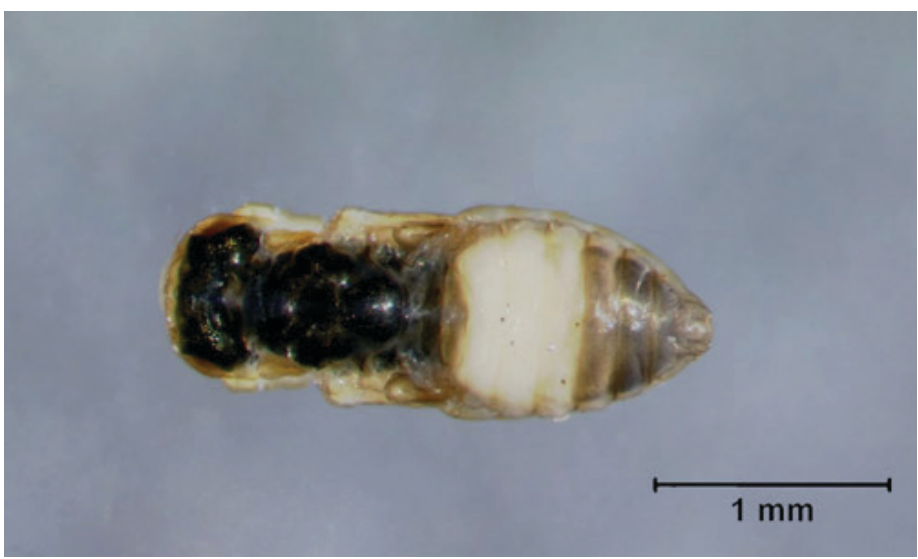

Figure 5. Muscidifurax raptor Girault \& Sanders pupa, dorsal view. Credits: Nicholas Tucker, UF/IFAS

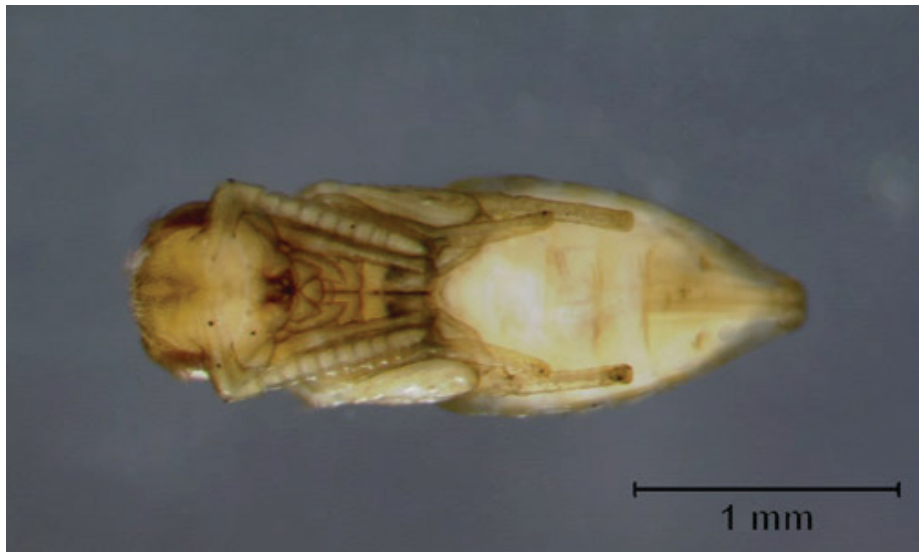

Figure 6. Muscidifurax raptor Girault \& Sanders pupa, ventral view. Credits: Nicholas Tucker, UF/IFAS

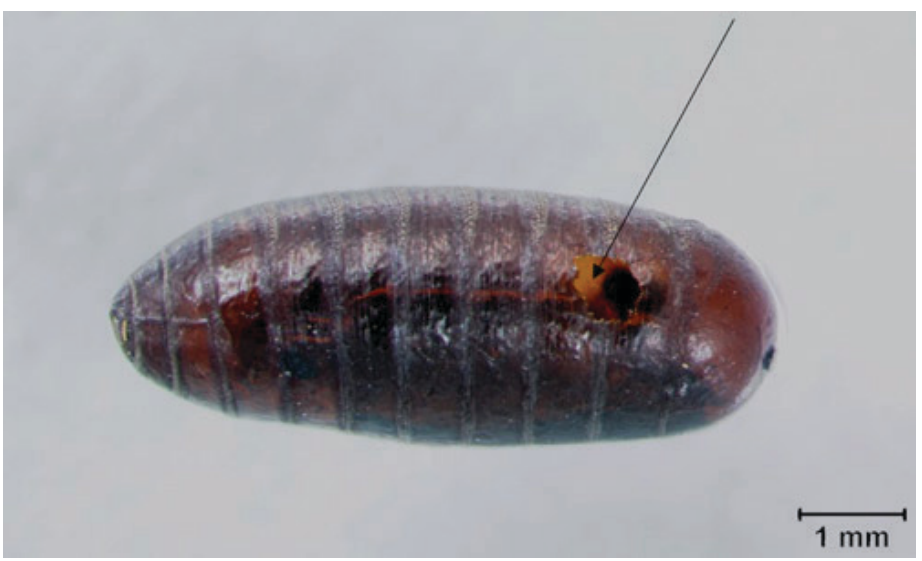

Figure 7. Musca domestica L. puparium with an emergence hole created by the adult Muscidifurax raptor Girault \& Sanders. Credits: Nicholas Tucker, UF/IFAS

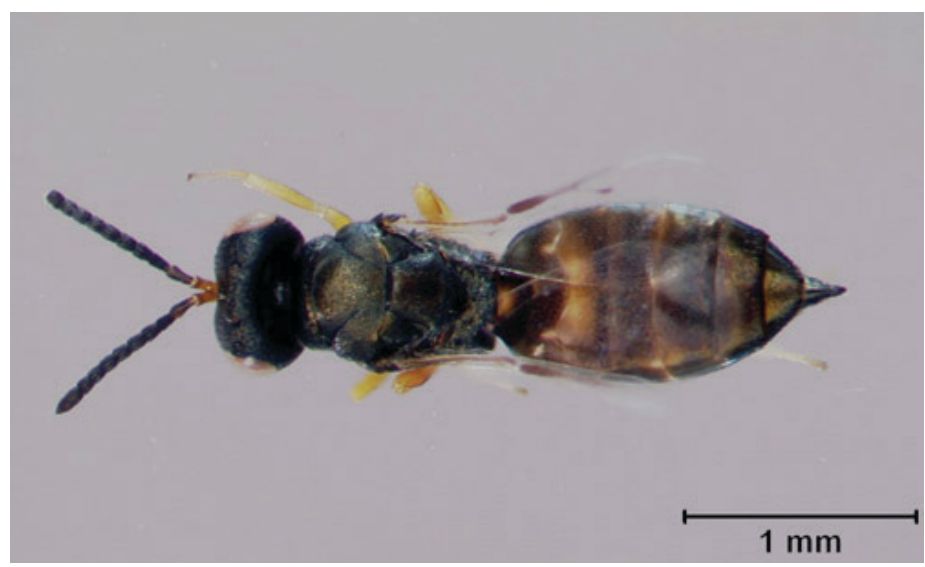

Figure 8. Muscidifurax raptor Girault \& Sanders adult, dorsal view. Credits: Nicholas Tucker, UF/IFAS

A female Muscidifurax raptor analyzes a fly puparium for oviposition suitability by drumming her antennae along the surface of the puparium. If the pupa already has been parasitized (by another wasp) or if the developing fly is dead, the female wasp will abandon that pupal case and continue searching until she finds an unparasitized and healthy pupa. She also may be able to determine host suitability by detecting the presence of host-marking pheromones, indicating previous oviposition (Vinson 1976). When a female Muscidifurax raptor does not recognize the marking pheromones of another parasitoid species and deposits an egg in a previously parasitized puparium, the Muscidifurax raptor larvae have been shown to outcompete other parasitoid species inside the puparium (Morgan 1981).

Once a suitable host is found, the female wasp will tap the tip of her abdomen on the surface of the fly puparium and drill through the puparium, inserting the entire length of her ovipositor and stinging the fly pupa within, which results in the death of the fly. She may then feed from the fly pupae by using her ovipositor to draw fly hemolymph (insect blood) to the surface of the puparium. After feeding, she may deposit a single egg on the external surface of the fly pupa or move to a different puparium for oviposition (Vinson 1976, Ridgeway and Vinson 1977). The act of laying a solitary egg, as opposed to multiple eggs per puparium, is a distinguishing factor between Muscidifurax raptor and other closely related parasitoids in natural situations. However, Muscidifurax raptor may lay multiple eggs under laboratory conditions or after mass field releases (Propp and Morgan 1983).

Under ideal conditions, a single Muscidifurax raptor female can parasitize, on average, 13 house fly pupae per day and an average of 100 throughout her lifespan (Morgan et al. 1979, Rueda and Axtell 1985). The larva hatches from the egg two to three days after being deposited and completes 
three larval instars over a 10-13 day period, followed by an 8-12 day pupal stage, with adult emergence about three weeks after the egg was laid. Males typically emerge 12-48 hours prior to females. Muscidifurax raptor is capable of both sexual and asexual reproduction. When asexual reproduction occurs only male offspring are produced. Production of only males results when a female has not mated.

\section{Hosts}

Muscidifurax raptor is a parasitoid of dipteran (true flies) pupae. It is known to deposit its eggs in 10 species of Diptera; most notable are the house fly, Musca domestica L.; the face fly, Musca autumnalis DeGeer; the secondary screw worm, Cochliomyia macelaria (Fabricius); the horn fly, Haematobia irritans (L.); and the stable fly, Stomoxys calcitrans (L.).

The house fly is a well-known pest of homes and farms where it is a nuisance and spreads pathogens by mechanical transmission. Musca domestica is known to vector Salmonella, Shigella, Campylobacter, Escherichia, Enterococcus, Chlamydia, and many other pathogens, many of which have been linked to food-borne illness outbreaks (SanchezArroyo and Capinera 1998). Due to a life cycle that can be completed in as little as seven days, house fly populations can grow to nuisance levels rapidly when favorable conditions are present.

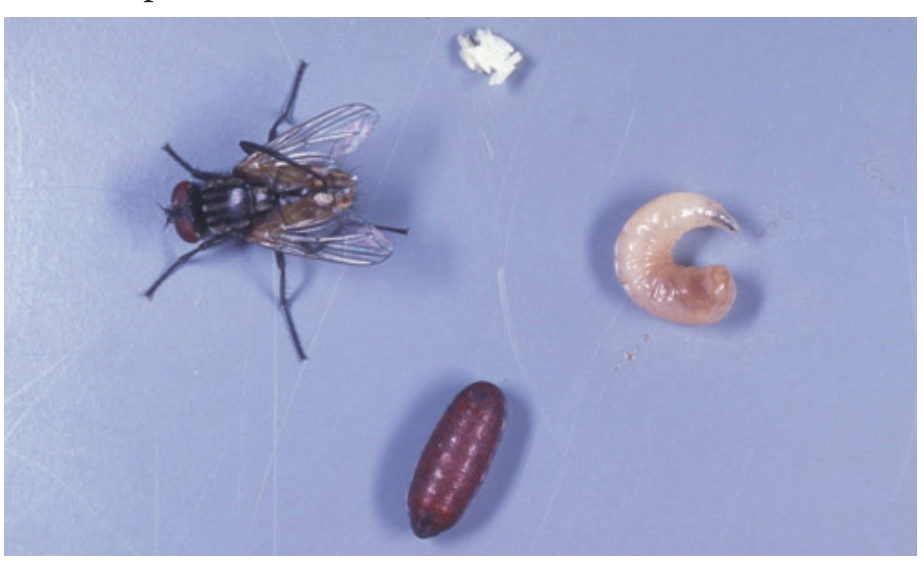

Figure 9. Egg, larva, pupa, and adult of the house fly, Musca domestica L.

Credits: Lyle J. Buss, UF/IFAS

The stable fly Stomoxys calcitrans is similar in size and color to the house fly, but has bayonet-like sucking mouthparts that protrude from the head. A single female can lay up to 600 eggs during her 30 day lifespan (Kaufman and Weeks 2015). Both males and females may take several blood meals each day. The stable fly typically inhabits barns and stables and is a nuisance to humans, horses, cattle, and other livestock due to its painful bite.

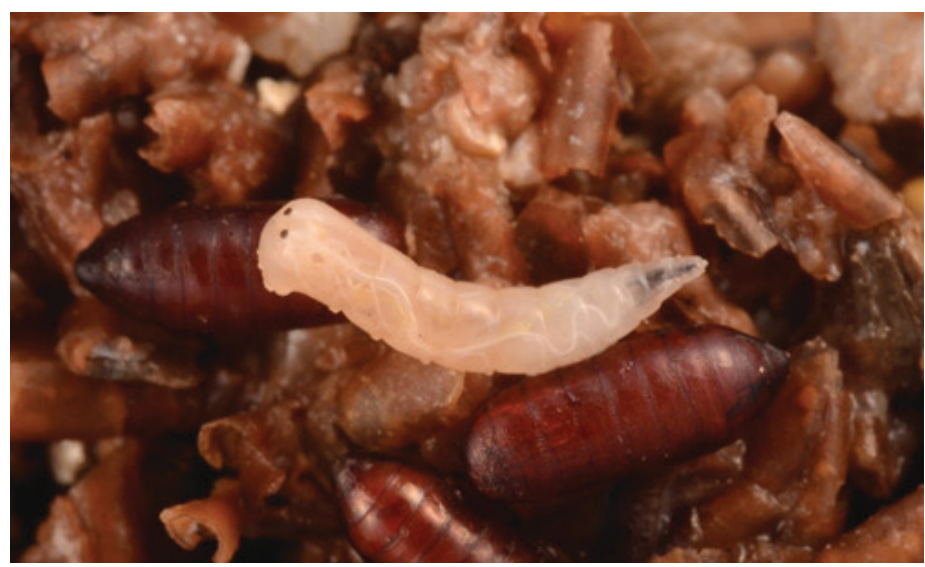

Figure 10. Reddish pupae and white larva of stable fly, Stomoxys calcitrans (L.).

Credits: Lyle J. Buss, UF/IFAS

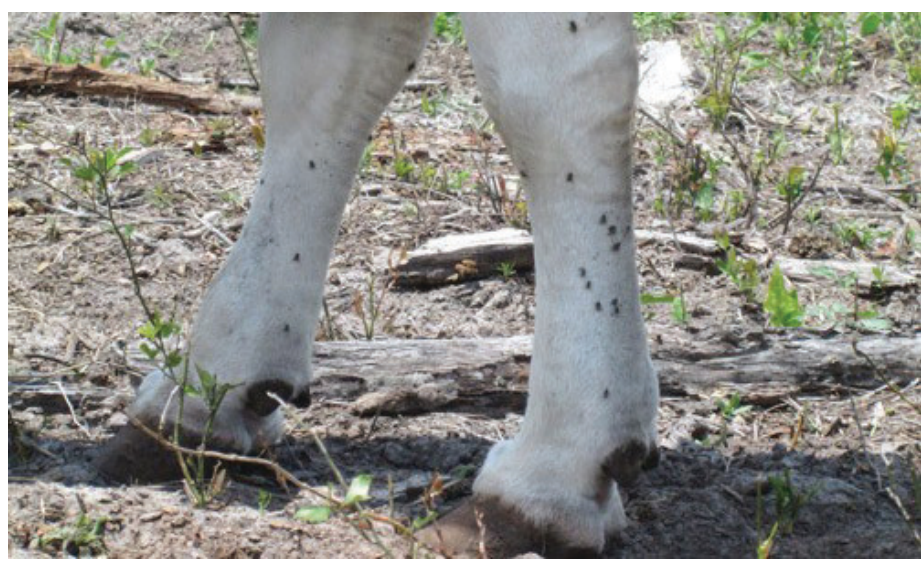

Figure 11. Adult stable flies, Stomoxys calcitrans (L.), feeding on lower legs of a cow.

Credits: Phillip Kaufman, UF/IFAS

Pupal parasitoids of Diptera can produce significant mortality in isolated fly populations. Muscidifurax raptor has been shown to reduce nuisance fly populations by as much as 35\% (Merritt et al. 1981). Due to the relatively short life cycles of filth flies, there typically will be a lag time between the population increase of the pest and an increase in the wasp population. In order to effectively manage filth fly populations, sustained weekly releases of parasitoids can be used, wherein livestock producers purchase and release substantial numbers of parasitoids (Meyer 1986).

\section{Economic Importance}

Nuisance insect pests are estimated to cost in the tens of billions of dollars worldwide in the form of reduced production of animal products (Patterson 1990). In many developing countries, livestock cannot be maintained due to excessive pest feeding or pathogen transmission by arthropods. Confined animal production systems have great potential for generating nuisance level filth fly populations. Biological control agents such as Muscidifurax raptor play an important role in integrated pest management of 
nuisance flies. In order to protect and preserve the beneficial predators and parasitoids within a system, the following guidelines should be used: keep manure dry with proper drainage, stagger manure removal schedules to provide harborage for beneficial organisms, and use insecticides selectively to minimize impact on beneficial predators and parasitoids (Axtell 1986). Overuse of insecticides can lead to the selection for insecticide resistance within a given pest population and can cause non-target pest outbreaks by removing natural predators from a system (Merritt et al 1981).

Campbell et al. (1977) determined that the sustained weekly release of 100 parasitoids per cow in feedlots was cost-effective when considering the potential animal product lost without parasitoid control of the stable fly. They found that a return of $\$ 3.60$ for each dollar invested could be achieved by using parasitoids as biological control agents. Due to the rapid developmental period of nuisance flies the timing of a parasitoid release is important. The optimum period for parasitoid release will depend on the local climate as nuisance species typically increase in response to warmer weather, but releases should occur as a pest population begins to rise, not after one is present at unacceptable levels. Monitoring for pest populations provides a good measure of pest abundance and will aid in improving pest management action decisions.

For more information on pestiferous flies use the following links:

\section{House fly, Musca domestica}

Secondary screwworm, Cochliomyia macellaria

Horn fly, Haematobia irritans irritans

Stable fly, Stomoxys calcitrans

For more information on biocontrol use the following links:

Natural enemies

Biocontrol guidelines

\section{Selected References}

Axtell RC. 1986. Status and potential of biological control agents in livestock and poultry pest management systems. Entomological Society of America. Miscellaneous Publication No. 61 pp 1-9.
Campbell JB, White RG, Wright JE, Crookshank R, Clanton DC. 1977. Effects of stable flies on weight gains and feed efficiency of calves on growing or finishing rations. Journal of Economic Entomology 70: 592-594.

Kaufman PE, Weeks ENI. (2015). Stable Fly (Dog Fly) Control. ENY267. Gainesville: University of Florida Institute of Food and Agricultural Sciences. (4 May 2016)

Lysyk TJ. 1999. Relationships between temperature and life history parameters of Muscidifurax raptor (Hymenoptera: Pteromalidae). Environmental Entomology. 29: 596-605.

Merritt RW, Gersabeck EF, Kennedy MK. 1981. The contribution of Spalangia endius and Muscidifurax raptor to stable fly management program on Mackinac Island, Michigan: A question of effort. United States Department of Agriculture Science and Education Administration. Status of Biological Control of Filth Flies. pp 44-51.

Meyer JA. 1986. Biological control of filth flies associated with confined livestock. Entomological Society of America. Miscellaneous Publication No. 61 pp. 108-115.

Morgan PB. 1981. The potential use of parasites to control Musca domestica L. and other filth flies and other filth breeding flies at agricultural installations in the southern United States. United States Department of Agriculture Science and Education Administration. pp 11-25.

Morgan PB, Weidhass DE, LaBrecque GC. 1979. Hostparasite relationship of the house fly, Musca domestica L., and the microhymenopteran pupal parasite, Muscidifurax raptor Girault and Sanders (Diptera: Muscidae and Hymenoptera: Pteromalidae). Journal of the Kansas Entomological Society 52: 276-281.

Patterson RS. 1990. Status of biological control of livestock pests. In Biocontrol of Arthropods affecting Livestock and Poultry. Westview Press, Boulder, CO. pp. 1-10.

Propp GD, Morgan PB. 1983. Multiparasitism of house fly, Musca domestica L., pupae by Spanglia endius Walker and Muscidifurax raptor Girault and Sanders (Hymenoptera: Pteromalidae). Environmental Entomology 12: 1232-1238.

Ridgeway RL, Vinson SB. 1977. Biological control by augmentation of natural enemies. Insect and Mite Control with Parasites and Predators. Plenum Press, New York. pp. 237-239. 
Rueda LM, Axtell RC. 1985. Guide to common species of pupal parasites (Hymenoptera: Pteromalidae) of the house fly and other muscoid flies associated with poultry and livestock manure. North Carolina Agricultural Research Service Technical Bulletin 278.

Sanchez-Arroyo H, Capinera JL. (2008). House fly, Musca domestica. EENY-48. Gainesville: University of Florida Institute of Food and Agricultural Sciences. (4 May 2016)

Smith L, Rutz DA. 1991. Microhabitat associations of hymenopterous parasitoids that attack house fly pupae at dairy farms in central New York. Environmental Entomology 20: 675-684.

Vinson SB. 1976. Host selection by insect parasitoids. Annual Review of Entomology 21: 109-133. 